\title{
OBSERVATIONS ON THE ACTION OF ACETONE.
}

BY

\author{
NOAH MORRIS, M.D., and STANLEY GRAHAM, M.D.
}

From the Institute of Physiology, University of Glasgow, and the Medical Department, Royal Hospital for Sick Children, Glasgow.

Ever since it has been shown that diabetic coma is associated with a marked acetonuria and acetonæmia, it has been suggested that the presence of acetone is the fons et origo of the symptoms of coma. Kussmaul( ${ }^{1}$ ) first investigated the pharmacological action of acetone experimentally on man, but with oral doses amounting to six grams he obtained no results. Using rabbits he found that the subcutaneous injections of acetone led to symptoms of intoxication and stupor, the action being less than that of chloroform or ether but stronger than alcohol. The symptoms were even more marked if the acetone was inhaled, and resembled clinically the coma of diabetes. Kussmaul accordingly concluded with the earlier workers that acetone was the direct cause of diabetic coma. Frerichs $\left({ }^{2}\right)$ gave large doses to men and dogs but without any special results and decided that acetone per se was not the cause of the coma. Penzoldt $\left({ }^{3}\right)$, however, as the result of his experiments on rabbits maintained that the acetone played an important role though it was not the only cause. Tappeiner( $\left.{ }^{4}\right)$ studied the effect of acetone inhalations on dogs and rabbits, and described two stages of acetone poisoning : first, a stage in which the blood pressure is raised with an increase in the pulse and respiration rates, and secondly, a stage of depression associated with a lowering of blood pressure, a decrease in the pulse and respiration rates and a gradual abolition of reflex activity. The second stage was marked by a steady fall in the temperature of the body until death ensued from respiratory failure. Prolonged inhalation of large amounts of acetone was required to produce the second stage. Albertoni ${ }^{5}{ }^{5}$ in a long series of experiments on dogs found that oral administration of acetone in doses amounting to 5 grams per kilo produced at most a slight fall in the systolic blood pressure, while on man the only effect to be observed was a slight narcosis. He also produced albuminuria in dogs with these large doses. Rhamy $\left(^{6}\right)$ stated that subcutaneous injections of acetone in guinea-pigs were more toxic than those of methyl alcohol. Hewlett $\left({ }^{7}\right)$, on the other hand, maintained that the toxicity of acetone was very low. Salant and Kleitman ${ }^{8}$, as a result of their experimental work concluded that acetone possesses a double action causing both depression and stimulation, but chiefly the former. They drew attention to the fact that although the amount of acetone present in the blood in acidosis is comparatively small, yet the tissues and the organs are exposed to its action for a relatively long period, and they inclined to the view that acetone per se is the cause of the symptoms in diabetic coma.

Allen and Wishart $\left({ }^{9}\right)$ have shown that young fasting animals and animals that have been phlorhizinised or depancreatised (in other words, suffering from 
carbohydrate starvation) are rendered more susceptible to the injection of acetone bodies. They also found that a hyperglycæmia resulted from the injection of acetone and the neutral salts of keto-acids.

In view of the varying experimental results the effect of acetone was considered worthy of further investigation.

\section{Effect of Acetone on the Nervous System.}

This effect was studied on rabbits and some of the results are recorded in Table 1. A $20 \%$ solution of acetone was injected intravenously, into the veins of the ear. In each case there was an interval of 24 hours between the injections to prevent cumulative action. Doses below $0.8 \mathrm{c.cm}$. pure acetone per kilo of body weight had no apparent effect on the animal. When, however, this dose was exceeded, it was found that the animals become stuporous and lay unconscious for a short period, usually 1 to 3 minutes. Recovery was fairly rapid and usually complete within three minutes. With very large doses convulsions were observed. These were clonic in type and lasted for much less than half the total period of unconsciousness. Reflexes were invariably abolished during the period of complete unconsciousness. The respirations during the period of coma were usually more rapid. The severity and duration of the symptoms were increased by increasing the dose of acetone, but not always proportionately. The rate of injection within limits ( 1 to 5 minutes) had no effect on the duration or severity of the symptoms produced.

TABLE I.

\begin{tabular}{|c|c|c|c|}
\hline Number. & $\begin{array}{l}\text { Weight of } \\
\text { Rabbit in } \\
\text { Kilos. }\end{array}$ & $\begin{array}{l}\text { Acetone per } \\
\text { Kilo. } \\
\text { cc. }\end{array}$ & Reaction. \\
\hline \multirow[t]{2}{*}{1} & 1.5 & $0 \cdot 4$ & Nil. \\
\hline & $1 \cdot 5$ & $0 \cdot 6$ & Nil. \\
\hline 22 & $1 \cdot 3$ & $0 \cdot 8$ & Nil. \\
\hline 1 & 1.5 & $1 \cdot 0$ & Unconscious for 30 sec. Recovery period 10 sec. \\
\hline 18 & 1.9 & $1 \cdot 0$ & Unconscious for 75 sec. Recovery rapid. \\
\hline \multirow[t]{2}{*}{4} & $1 \cdot 1$ & $1 \cdot 2$ & Unconscious for 30 sec. Recovery period 60 sec. \\
\hline & $1 \cdot 1$ & $1 \cdot 2$ & Same result. This dose given $10 \mathrm{~min}$. after previous one. \\
\hline 1 & $1 \cdot 5$ & $1 \cdot 3$ & Unconscious for 60 sec. Recovery period 10 sec. \\
\hline 4 & $1 \cdot 1$ & $2 \cdot 4$ & $\begin{array}{l}\text { Convulsions for } 2 \frac{1}{2} \text { min. Respiration rapid. Nystagmus. } \\
\text { Regained balance in } 8 \mathrm{~min} \text {. Still dazed at end of } 17 \\
\text { min. }\end{array}$ \\
\hline
\end{tabular}

The effects of Intravenous Injections of $20 \%$ Acetone Solution.

Hirschfeld $\left({ }^{10}\right)$, in 1895 , pointed out that the presence of carbohydrates prevented the formation of acetone bodies and Shaffer $\left({ }^{11}\right)$, in 1921, showed that the oxidation of acetone was greatly accelerated by the presence of glucose. Geelmuyden $\left({ }^{12}\right)$ has also suggested that a combination of acetone bodies and 
carbohydrate was necessary before the former could be oxidised. In order to test if glucose was able to prevent or minimise the toxic symptoms, a $10 \%$ solution of glucose was injected simultaneously with the acetone. In every case the period of unconsciousness was shortened and in two cases the occurrence of convulsions was prevented. In some experiments glucose was also injected 5 minutes before the acetone and invariably there resulted not only shortening of the duration of the reaction but a diminished intensity of the toxic effects on the nervous system.

The value of alkali in the treatment of ketosis has long been known and until recently occupied a prominent place in the treatment of diabetic coma. In a series of experiments in which the acetone was injected along with $6 \%$ sodium bicarbonate solution, the effect observed was similar to that of the simultaneous injection of glucose. When, however, the sodium bicarbonate solution was administered before the acetone, its preventive action was much stronger than that of glucose.

These results are tabulated in Tables II and III. In one case, the same amount of saline was injected previously instead of glucose or bicarbonate solution in order to rule out the possible effect of the fluid per se.

TABLE II.

\begin{tabular}{|c|c|c|c|c|}
\hline $\begin{array}{c}\text { Number } \\
\text { of } \\
\text { Animal. }\end{array}$ & $\begin{array}{l}\text { Weight } \\
\text { in } \\
\text { Kilos. }\end{array}$ & $\begin{array}{l}\text { Acetone per } \\
\text { Kilo. } \\
\text { cc. }\end{array}$ & Remarks. & Reaction. \\
\hline 1 & 1.5 & $\begin{array}{l}1 \cdot 3 \\
1 \cdot 3\end{array}$ & $\begin{array}{l}8 \text { cc. } 20 \% \text { glucose soln. } \\
\text { simultaneously. }\end{array}$ & $\begin{array}{l}\text { Unconscious } 30 \text { sec. Recovery } \\
\text { period } 10 \text { secs. } \\
\text { Nil. }\end{array}$ \\
\hline 2 & $2 \cdot 0$ & $\begin{array}{l}1 \cdot 2 \\
1 \cdot 2 \\
1 \cdot 2 \\
1 \cdot 2\end{array}$ & $\begin{array}{l}10 \text { cc. } 20 \% \text { glucose } \\
\text { soln. simultaneously. } \\
10 \text { cc. } 40 \% \text { glucose } \\
\text { soln. simultaneously. } \\
10 \text { cc. } 6 \% \text { NaHCO } \\
\text { soln. simultaneously. }\end{array}$ & $\begin{array}{l}\text { Unconscious } 3 \text { mins. Recovery } \\
\text { period } 2 \text { mins. } \\
\text { Dazed } 10 \text { sec. } \\
\text { Dazed } 10 \text { sec. } \\
\text { Unconscious } 30 \text { sec. Recovery } \\
\text { period } 2 \text { min. }\end{array}$ \\
\hline 3 & $1 \cdot 2$ & $\begin{array}{l}1 \cdot 2 \\
1 \cdot 2 \\
1 \cdot 2\end{array}$ & $\begin{array}{l}6 \text { cc. } 20 \% \text { glucose } \\
\text { simultaneously. } \\
6 \begin{array}{c}\text { cc. } 6 \% \text { NaHCO } \\
\text { simultaneously. }\end{array}\end{array}$ & $\begin{array}{l}\text { Convulsion. Unconscious for } \\
3 \text { min. Recovery period } 3 \text { min. } \\
\text { Unconscious } 30 \text { sec. Recovery } \\
\text { period } 2 \frac{1}{2} \text { mins. } \\
\text { Unconscious } 20 \text { sec. Recovery } \\
40 \text { sec. }\end{array}$ \\
\hline
\end{tabular}

The effect of Injections of Acetone modified by simultaneous injections of Glucose or Sodium Bicarbonate.

\section{Effect of Acetone on the Respiration.}

As a general rule the effect of acetone on the breathing was an increase in both rate and depth. Occasionally, this increase in minute volume was preceded by a short period of apnœa. In rabbits, the respiratory rate and depth were always increased, leading in one case to an increase in minute volume of $340 \%$. In cats, there was occasionally observed a very slight depression of the respiratory rate together with a decrease in the depth of the individual 
respirations. Repeated doses produced no increase of effect in rabbits but in cats the period of apnœa was greatly prolonged. Both in cats and rabbits, the effect very soon passed off although the blood contained a very large amount of acetone (303 $\mathrm{mgm} . \%$ in one case).

TABLE III.

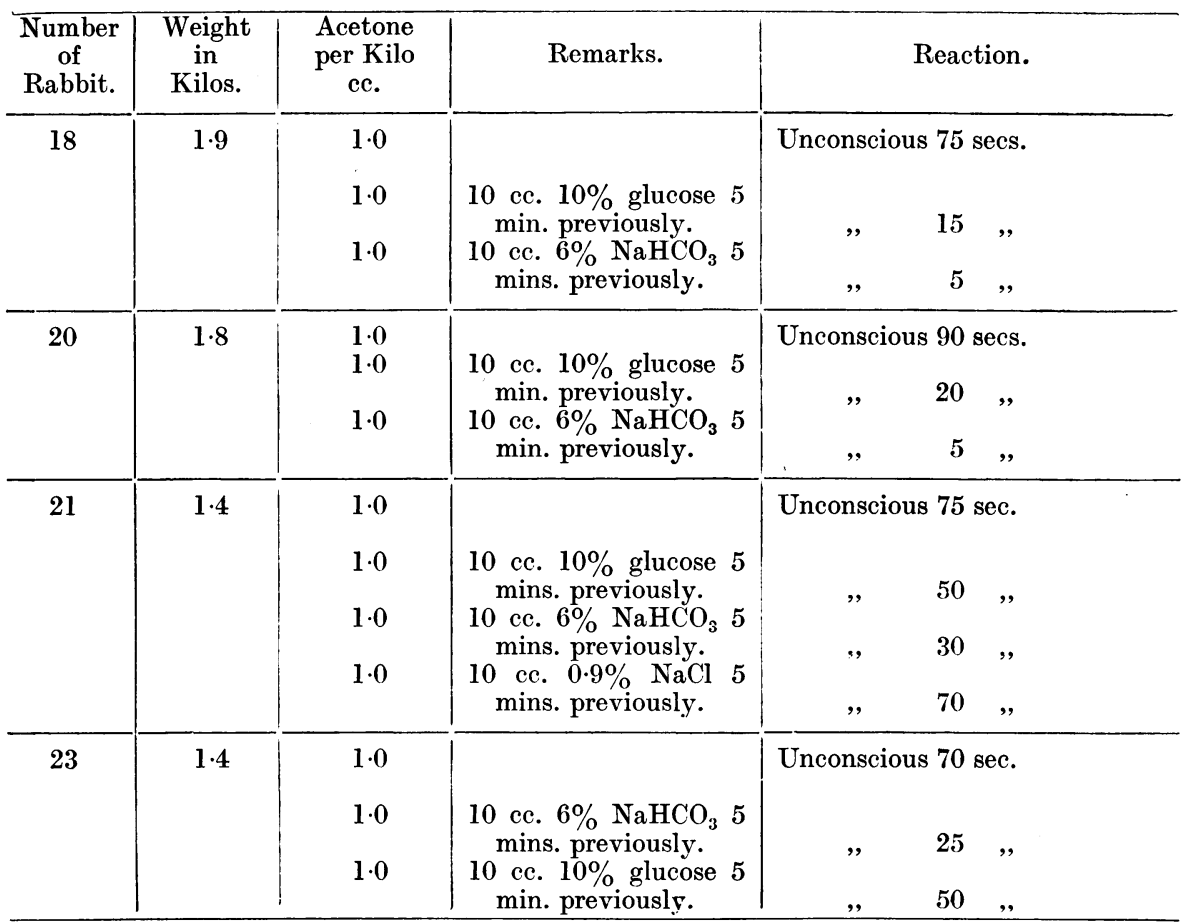

The effect of injections of Acetone modified by previous injections of Glucose or Sodium Bicarbonate.

Injection of either glucose or bicarbonate along with the acetone did not alter the effect of the acetone on the respiration, nor was the previous injection of these substances more efficient. With lethal doses, respiratory failure took place some minutes before the heart ceased to beat, thus confirming the observation of Salant and Kleitman ${ }^{8}$ ).

\section{Effect of Acetone on the Circulation.}

In all cases acetone injections led to a fall in the blood pressure unless the injection was very slow when practically no effect was observed. On one or two occasions a slight rise preceded the fall. Previous injections of glucose seemed occasionally to lessen the fall. The rate of recovery depended for the most part on the period of apnœa. The recommencement of the respiratory movements was usually accompanied by a fairly sharp rise in the blood pressure. Administration of suprarenal extract was more than sufficient to counteract the fall of blood pressure due to the acetone. 


\section{Excretion of Acetone.}

In all cases, irrespective of the dose, acetone was excreted within twenty hours of its administration, the complete excretion being determined by its disappearance from the urine. One fact of interest may here be noted, viz., that within half an hour of the administration of a large dose of acetone, the blood-acetone bodies were not nearly as high as might have been expected. For example, in one case where $14.5 \mathrm{cc}$. of $20 \%$ acetone were injected, the blood should have contained $2.9 \mathrm{cc}$. acetone if none had been excreted. The total acetone bodies were determined on a sample of blood taken approximately 5 minutes after the injection and were found to be $0 \cdot 303 \%$. Taking the bloodvolume as one-thirteenth of the body weight, this represents only 0.56 grms.roughly one-fifth of the amount injected. The urine at this time was free of acetone and as there was no perceptible odour of acetone in the breath, it seems unlikely that the other $4 / 5$ ths, or $2 \cdot 3$ grms., were excreted by the lungs. This suggests that the acetone was dealt with by the tissues in some way.

\section{Effect of Acetone on the Blood Sugar.}

Some observations were also made on the effect of acetone on the blood sugar. The animals were in all cases starved for twenty-four hours and the fasting blood sugar estimated. Results were neglected unless the fasting blood sugar value was between $0 \cdot 100$ and $0 \cdot 125 \%$. The acetone was injected into the ear veins and the blood was taken from these veins at intervals after the injection. The results are given in Table IV.

TABLE IV.

\begin{tabular}{|c|c|c|c|c|c|c|c|c|}
\hline \multirow{2}{*}{ Number. } & \multirow{2}{*}{$\begin{array}{c}\text { Weight } \\
\text { of } \\
\text { Animal. }\end{array}$} & \multirow{2}{*}{$\begin{array}{l}\text { Acetone } \\
\text { per } \\
\text { kilo cc. }\end{array}$} & \multirow{2}{*}{$\begin{array}{l}\text { Fasting } \\
\text { Blood } \\
\text { Sugar. }\end{array}$} & \multicolumn{5}{|c|}{ Blood Sugar at end of- } \\
\hline & & & & $5 \mathrm{~min}$. & $15 \mathrm{~min}$. & $30 \mathrm{~min}$. & $45 \mathrm{~min}$. & $60 \mathrm{~min}$. \\
\hline 4 & $1 \cdot 1$ & $1 \cdot 2$ & $\cdot 115$ & $\cdot 154$ & $\cdot 166$ & 一 & - & - \\
\hline 5 & 1.05 & $1 \cdot 2$ & $\cdot 119$ & $\cdot 113$ & $\cdot 118$ & $\cdot 113$ & - & - \\
\hline 8 & $2 \cdot 15$ & $1 \cdot 0$ & $\cdot 107$ & $\cdot 110$ & $\cdot 139$ & $\cdot 106$ & $\cdot 108$ & $\cdot 100$ \\
\hline 9 & 1.4 & 0.5 & $\cdot 125$ & $\cdot 111$ & $\cdot 169$ & $\cdot 164$ & $\cdot 149$ & - \\
\hline 10 & 1.2 & $0 \cdot 3$ & $\cdot 117$ & $\cdot 128$ & $\cdot 156$ & - & $\cdot 119$ & 一 \\
\hline 11 & 2.15 & water & $\cdot 117$ & $\cdot 127$ & $\cdot 117$ & $\cdot 117$ & $\cdot 109$ & - \\
\hline
\end{tabular}

The effect of Injections of Acetone on the fasting Blood Sugar.

In every case except one there is a slight rise in the blood sugar following the injection of acetone. The rise in the blood sugar is not directly proportionate to the dose of acetone-in fact the smaller doses gave the greater rise. It is quite conceivable that if the dose of acetone is large enough to produce convulsions, no rise in the blood sugar would occur, because it has been definitely shown that convulsions themselves will cause a fall in the blood sugar.

In no case did the rise in blood sugar lead to a glycosuria. The presence of glycosuria following the injections of acetone has been recorded by von Jaksch $\left({ }^{13}\right)$ 
and others. Von Noorden( $\left.{ }^{14}\right)$ also states that hyperglycæmia and glycosuria occur after the administration of acetone and seems to be quite definite in his contention that this condition is the result of deficiency of oxygen. In none of our experiments was there ever a hyperglycæmia great enough to cause a suspicion of a glycosuria even when taken at the end of an apnœic period. It seems to us that the slight rise cannot be attributed to defective oxidation of the blood, although the possibility still remains that acetone inhibits the oxidation processes in the cells.

\section{Effect of Acetone on the $\mathrm{CO}_{2}$-Content and the $\mathrm{CO}_{2}$-Combining Power OF THE BLOOD.}

In two cases the total $\mathrm{CO}_{2}$-content of the arterial blood was determined as well as three points on the $\mathrm{CO}_{2}$-dissociation curve. For ready comparison Table $\mathrm{V}$ shows the volumes per cent. of $\mathrm{CO}_{2}$ taken up by the blood when exposed to tensions of $\mathrm{CO}_{2}$ of 20,40 and $60 \mathrm{~mm}$. before and after the intravenous administration of $10 \mathrm{cc}$. of $20 \%$ acetone to cats.

TABLE V.

\begin{tabular}{|c|c|c|c|c|c|c|}
\hline & & \multicolumn{3}{|c|}{ Volumes of $\mathrm{CO}_{2} \%$ taken up at- } & \multirow{2}{*}{$\begin{array}{l}\mathrm{CO}_{2} \text {-content of } \\
\text { Arterial Blood. }\end{array}$} & \multirow{2}{*}{$p \mathrm{H}$} \\
\hline & & $20 \mathrm{~mm}$. & $40 \mathrm{~mm}$. & $60 \mathrm{~mm}$. & & \\
\hline Cat. 1.-Before & $\cdots$ & $33 \cdot 5$ & $47 \cdot 0$ & $54 \cdot 5$ & $54 \cdot 6$ & $7 \cdot 20$ \\
\hline After ... & $\ldots$ & $31 \cdot 8$ & $45 \cdot 8$ & $52 \cdot 3$ & $53 \cdot 8$ & $7 \cdot 15$ \\
\hline Cat. 2.-Before & $\cdots$ & $36 \cdot 5$ & $48 \cdot 5$ & $56 \cdot 0$ & $44 \cdot 6$ & $7 \cdot 38$ \\
\hline After ... & $\ldots$ & $31 \cdot 5$ & $44 \cdot 5$ & $51 \cdot 2$ & $45 \cdot 0$ & $7 \cdot 31$ \\
\hline
\end{tabular}

It will be seen that in each case there is a slight decrease in the $\mathrm{CO}_{2}$ combining power, that is, the curve is shifted slightly to the right, although in the first case the difference is probably almost within the limits of experimental error. The $p \mathrm{H}$ values before and after the injections were worked out from the information obtained above by means of the arterial point on the dissociation curve and the application of Hasselbalch's equation. These figures are also given in Table $\mathrm{V}$. In each case there is a definite fall in the $p \mathrm{H}$ indicating an acid-poisoning effect of the acetone. Apropos of the low initial $p \mathrm{H}$ of the blood of Cat 1 , it should be mentioned that in each case the animal was under the influence of urethane, which may have accounted for the low figure recorded before the injection.

\section{Discussion.}

The results of acetone injection show a close resemblance to those produced by acid poisoning. The same effect on respiration and circulation have been described as occurring after injections of acids such as phosphoric acid or hydrochloric acid by Mathison(15). It is an old observation that both oral and intravenous administration of acids leads to glycosuria( $\left.{ }^{16}\right)$. This close similarity in effects leads us to think that the symptoms of acetone poisoning may be due, in part at least, to acid-poisoning of the blood, It may be argued 
that this change in acid-base equilibrium is secondary to the effect on respiration as produced by the action on the respiratory centre. In some of the experiments, however, the effect on the blood sugar occurred without any change in the nervous activity. As a matter of fact, the most pronounced rise of blood sugar occurred with the small doses and when the rabbit showed no nervous symptoms. This conclusion is supported by the beneficial effects resulting from preceding injections of sodium bicarbonate. The results with glucose, although not so striking as those with bicarbonate, are of interest in that they are in accord with what has been long known clinically, viz. : that administration of glucose is one of the best methods of treating a ketosis.

At the same time it is very clear from our results that the effect of acetone is not limited merely to an alteration of the acid base balance. It has also a direct action on the central nervous system not unlike that of alcohol, particularly methyl alcohol, the toxic action of which is frequently manifested by convulsions. This narcotic action is apparently influenced by the presence of alkali and glucose, and in order to produce it large doses of acetone must be injected.

It would seem that this double action of acetone is frequently lost sight of in assessing the influence of various factors in the production of coma. As has been pointed out by many investigators $\left({ }^{8}\right)\left({ }^{17}\right)$, it is hardly fair to compare the results of an acute intoxication with acetone on the cells of an animal that is previously normal, with the gradual and continuous action of small percentages of acetone over long periods. In the latter case the acetone is having a continuous effect on the acid-base equilibrium and the organism is in a condition of stress in the constant effort to maintain a normal reaction. It may be that in this way the cells become more liable to the narcotic action of acetone so that at a certain stage in the condition with the gradual rise in the acetonæmia, coma sets in, although the actual percentage of acetone is much below that found to be necessary for the experimental production of coma.

\section{Conclusions.}

1. Experiments were done on cats and rabbits to demonstrate the effects of acetone administered intravenously.

2. Doses of acetone exceeding $0.8 \mathrm{cc}$. per kilo body weight produced unconsciousness, occasionally with clonic convulsions. The respiratory minute volume was increased. The blood pressure was lowered, with a preliminary slight rise, on a few occasions.

3. In each case the urine was free of ketone bodies within twenty hours of the administration of acetone, irrespective of the dose.

4. In all cases but one there was a slight but definite rise in blood-sugar following intravenous injection of acetone.

5. In two cases the $\mathrm{CO}_{2}$-dissociation curve of the arterial blood was determined, and the $p \mathrm{H}$ of the "arterial" point calculated. In both cases there was a slight shift to the acid side. 
6. Previous or simultaneous injection of glucose or sodium bicarbonate always lessened the intensity of the acetone effect. Sodium bicarbonate seemed slightly the more efficacious.

7. The suggestion is made that acetone has a double action : (1) a toxic effect similar to that of methyl alcohol and (2) an acid effect on the acid-base equilibrium.

We desire to thank Professor L. Findlay for his helpful advice and criticism throughout the course of the research. Our thanks are also due to the Medical Research Council with whose aid the work has been done.

\section{REFERENCES.}

1. Kussmaul, A., Deut. Arch.f. klin. Med., Leipzig, 1874, XIV, 1.

2. Frerichs, F. T., Ztsch.f. klin. Med., Berlin, 1883, VI, 1.

3. Penzoldt, F., Deut. Arch.f. klin. Med., Leipzig, 1884, XXXIV, 127.

4. Tappeiner, H., Ibid, Leipzig, 1884, XXXIV, 450.

5. Albertoni, P., Arch.f. exp. Path. u. Pharm., Leipzig, 1884, XVIII, 218.

6. Rhamy, B. W., J. Amer. Med. Ass., Chic., 1912, LVIII, 628.

7. Hewlett, A. W., The Pathological Physiology of Internal Diseases, N.Y. and Lond., 1923.

8. Salant, W., and Kleitman, N., J. Pharm. and Exp. Therap., Balt., 1922, XIX, 293.

9. Allen, F. M. and Wishart, M. B., J. Metab. Res., N. Jersey, 1923, IV, 613.

10. Hirschfield, F., Ztschr. f. klin. Med., Berlin, 1895, XVIII, 176.

11. Shaffer, P. A., J. Biol. Chem., Baltimore, 1921, XLIX, 143.

12. Geelmuyden, H. C., Ztschr. physiol. Chem., Berlin, 1904, XLI, 135.

13. Von Jaksch, R., Ztschr.f. klin. Med., Berlin, 1885, X, 362.

14. Von Noorden, C., Metabolism and Practical Medicine, London, 1907, III, 1099.

15. Mathison, G. C., J. Physiol, Camb., 1910-11, XLI, 416.

16. Pavy, F. W., Diabetes Mellitus, Lond., 1869, 154.

17. Wells, H. G., Chemical Pathology, Philad., 1920. 